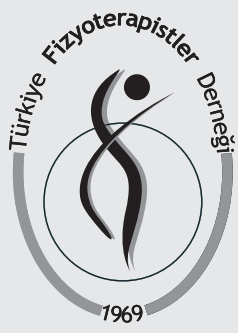

ISSN: $2651-4451 \cdot e-I S S N: 2651-446 X$

\section{Türk Fizyoterapi ve Rehabilitasyon Dergisi}

$201930(1) 23-32$

Sevim ACARÖZ CANDAN, PhD, $\mathrm{PT}^{1}$ Ayşe LIVANELIOǦLU, PhD, $\mathrm{PT}^{2}$

\title{
EFFICACY OF MODIFIED CONSTRAINT-INDUCED MOVEMENT THERAPY FOR LOWER EXTREMITY IN PATIENTS WITH STROKE: STRENGTH AND QUALITY OF LIFE OUTCOMES
}

\section{ORIGINAL ARTICLE}

\section{ABSTRACT}

Purpose: This study was aimed to examine the efficacy of modified constraint-induced movement therapy (mCIMT), which was applied to lower extremity, on strength and quality of life (QoL) in patients with stroke.

Methods: Thirty patients with stroke were randomly divided into two groups. Both groups received neuro-developmental therapy (NDT) for four weeks as baseline treatment. After four weeks, when the study group received mCIMT, the control group continued NDT for two weeks as the experimental treatment. The strength was evaluated using Motricity Index, and QoL was evaluated using Stroke Specific Quality of Life Scale (SS-QoL), and Stroke Impact Scale (SIS) for three times (baseline, post 4 weeks, and post 6 weeks).

Results: The strength and QoL improved in both groups for all treatment periods $(p<0.01)$. The paretic lower limb strength developed more in the mCIMT group for the total treatment period $(p=0.029)$. The total score of the SS-QoL and mobility, self-care, thinking, mood, family, and social roles subdomain scores of the SS-QoL were more pronounced in the mCIMT group after the MCIMT period $(p<0.05)$. The amount of perceived recovery domain of SIS was greater in the mCIMT group after $\mathrm{mCIMT}$ and total treatment periods according to the control group $(\mathrm{p}<0.001)$. The total changes in strength and QOL were strongly correlated with the improvement in the mCIMT period $(r=0.709$, $p<0.01$ and $r=0.769, p<0.01)$ than in the baseline period $(r=0.660, p<0.01$ and $r=0.505, p<0.01)$.

Conclusion: The study showed that mCIMT could be used as an effective treatment method for patients with stroke to improve paretic lower extremity strength and health-related QoL.

Key Words: Muscle Strength; Quality of Life; Stroke Rehabilitation.

\section{INMELI HASTALARDA ALT EKSTREMITEYE UYGULANAN MODIFIYE KISITLAYICI-ZORUNLU HAREKET TEDAVISININ ETKINLIǦi: KUVVET VE YAŞAM KALITESI SONUÇLARI}

\section{ARAŞTIRMA MAKALESI}

Ordu University, Faculty of Health Sciences, Department of Physiotherapy and Rehabilitation, Turkey.

2 Department of Physiotherapy and Rehabilitation, Faculty of Health Sciences, Hacettepe University, Ankara, Turkey.

İletişim (Correspondence):

\section{Sevim ACARÖZ CANDAN, PhD, PT} Ordu University,

Faculty of Health Sciences, Department of Physiotherapy and Rehabilitation, 52100, Ordu, Turkey.

Phone: +90-452-2265248

E-mail:fzt_acaroz@hotmail.com ORCID ID: 0000-0002-2617-8865

Ayșe LIVANELIOČLU E-mail: alivanelioglu@yahoo.com ORCID ID: 0000-0002-3609-5166

Geliş Tarihi: 15.03.2018 (Received) Kabul Tarihi: 13.08.2018 (Accepted)

\section{öz}

Amaç: Bu çalışmanın amacı inmeli hastalarda alt ekstremiteye uygulanan modifiye kısıtlayıcı-zorunlu hareket tedavisinin (mKZHT) kuvvet ve yaşam kalitesi (YK) üzerine etkinliğini değerlendirmekti.

Yöntem: Otuz inmeli hasta rastgele iki gruba ayrıldı. Her iki gruba başlangıç tedavisi olarak dört hafta süre ile nörogelişimsel tedavi (NGT), ardından iki hafta süreyle çalışma grubuna deneysel tedavi olarak mKZHT, kontrol grubuna ise NGT uygulandı. Kuvvet Motrisite İndeksi ile, YK ise İnmeye Özgü Yaşam Kalitesi Ölçeği (IÖYKÖ) ve İnme Etki Ölçeği (IEÖ) ile üç kez (başlangıçta, 4 hafta sonra ve 6 hafta sonra) değerlendirildi.

Sonuçlar: Kuvvet ve YK her iki grupta da tüm tedavi periyodları sonrasında gelişti $(p<0,01)$. Paretik alt ekstremite kuvveti toplam tedavi periyodunda mKHZT grubunda daha fazla gelişti $(p=0,029)$. iÖYKÖ toplam puanı ve IÖYKÖ mobilite, kendine bakım, düşünme, ruh hali, aile ve sosyal roller alt alan puanlarında deneysel tedavi periyodu sonrasında görülen değişim mKHZT grubunda daha fazlaydı $(p<0,05)$. mKHZT grubunda hem mKHZT tedavi hem de toplam tedavi periyodu sonrasında IEÖ'nde algılanan iyileşme miktarındaki artış kontrol grubuna göre daha fazlaydı $(p<0,01)$. Kuvvet ve YK'deki toplam değişimler, mKHZT periyoddaki gelişmeler $(r=0,709, p<0,01$ ve $r=0,769, p<0,01)$ ile başlangıç periyodundaki gelişmelere ( $r=0,660, p<0,01$ ve $r=0,505, p<0,01)$ göre daha güçlü ilişkideydi.

Tartışma: Bu çalışma inmeli hastalarda paretik alt ekstremite kuvvetini ve sağlıkla ilişkili YK geliştirmede mKZHT'nin etkili bir tedavi yöntemi olarak kullanılabileceğini göstermektedir.

Anahtar Kelimeler: İnme Rehabilitasyonu; Kas Kuvveti; Yaşam Kalitesi. 


\section{INTRODUCTION}

Stroke is one of the significant factors for disability and mortality in the developed world (1). Patients with stroke can live longer, despite the high rates of disability and morbidity associated with stroke (2). Disability and morbidity elicit an attenuation in quality of life (QoL) in patients with stroke (3). The QoL has a multidimensional structure that includes physical, psychologic, functional, and social health-related domains. Carod et al. showed that mobility and muscle strength were the most highly correlated domains with health-related QoL (4). Therefore, rehabilitation programs, which are aimed to improve QoL, should be targeted primarily at the mobility and strength of paretic lower extremity. There are many different rehabilitation approaches to improve lower extremity function (5). Regardless of which the rehabilitation approach used, first it is necessary to break the "learned misuse" phenomenon that has developed in the lower extremity because one of the main problems following stroke is the misuse of paretic lower extremity during mobility (6). Some authors have reported that patients with stroke are in tendency prefer to use the nonparetic lower extremity during functional activities and even during exercise sessions depending on the inefficacy in weightbearing tasks of paretic extremity (7). Despite this inclination to use the nonparetic extremity, the practicability and efficiency of the rehabilitation approaches which promote the use of paretic lower extremity should be improved (8).

In recent years, constraint-induced movement therapy (CIMT) or modified CIMT, which was first used for upper extremity rehabilitation, has begun to be used for lower extremity as well (9-12). Even though there are some difficulties for lower extremity rehabilitation with $\mathrm{mCIMT}$ in clinical settings, many researchers have tried it nonetheless and have shown that CIMT or MCIMT significantly improved motor functions $(9,10,12-14)$.

However, to our knowledge, the effects of mCIMT on the lower extremities on QoL and muscle strength have not yet been investigated. Therefore, the present study aimed to evaluate the efficacy of mCIMT on QoL and muscle strength in stroke survivors. In addition, we also investigated the association between the total developments in muscle strength and QoL and particular change according to the treatment period.

\section{METHODS}

\section{Study Design and Participants}

This study was designed as a prospective, singleblind, randomized controlled study. The sample size was determined by $G^{*}$ Power 3.0.10 (G*Power 3.1 software, F. Faul, E. Erdfelder, A.G. Lang and A. Buchner, University of Kiel, Germany; http://www. gpower.hhu.de). The confidence level was set at 5\% with power $80 \%$. An average difference between groups for the SIS score was postulated 9.09 according to a previous study (15). The sample size calculated as 11, but at least 15 participants were included in each group to prevent dropouts. Before they were randomized into two groups, the participants were stratified based on age $(\leq 60$ or $>60$ years), gender, hemiplegic side, type of stroke, and length of time post-stroke to obtain a balanced distribution of the participants according to essential parameters which have known prognostic effects by a physiotherapist (16). The participants were identified into blocks, and simple randomization is performed using computergenerated random numbers.

Inclusion criteria were as follows: clinical diagnosis of a single, unilateral stroke; being over the age of 18 years; the time since the stroke was between 3 and 12 months; the exhibition of mild to moderate disability according to lower extremity recovery stages (Brunnstrom recovery stages (III-V); no attendance in any rehabilitation programme; and permitted to participate in an intensive rehabilitation program. Patients were excluded if they had a recurring stroke; medical comorbidities; cognitive impairment (less than 24 points on the Mini-Mental Status Examination); additional neurological or orthopedic problems. Patients were also excluded from the study if they missed $\geq 3$ consecutive treatment sessions. It was especially noted that the medical condition of the participants was stable and had not previously received physiotherapy, so the participants were called from the patient list, that waiting to receive physiotherapy for the first time. Signed informed consent was obtained from all participants, as approved by the Hacettepe University Ethics Committee (GO 14/22-15). 


\section{Outcome Measures}

All participants were evaluated by a physiotherapist who was blinded to their grouping, a total of three times, at baseline, post 4 weeks, and post 6 weeks.

The Motricity Index is a useful, valid and reliable assessment tool for muscle strength that can predict mobility outcomes poststroke (17). Hip flexion, knee extension, and ankle dorsiflexion were graded based on weighted scores between 0 and 33, as Motricity Scores (18). During the test, the patient applied force against resistance. The score was recorded according to the quality of muscle contraction. Finally, all three scores were summed with 1 more point added. Then, the scores for the lower extremities, which changed from 0 (paresis) to 100 (normal), were calculated.

Quality of life was determined using the Turkish version of the Stroke Specific Quality of Life (SSQoL) scale (19). This tool is a patient-oriented questionnaire including of 12 domains, such as self-care, vision, language, mobility, work, upper extremity, thinking, personality, mood, family, social roles, and energy. Each domain scored between 1 and 5 (20). A total score and the score of each subdomain were calculated separately.

The Turkish translated Stroke Impact Scale (SIS), version 3.0, was used to determine the impact of stroke on patients (21). The SIS contains eight domains, but only the lower extremity strength (2 items), mobility (9 items) domains were used in the present study. Each item is scored on a 5 -point scale, and total scores of each domain could change between 0 and 100. In addition, one question investigates the amount of the perceived recovery after stroke using a Visual Analogue Scale, on 100 scores (22).

\section{Intervention}

The treatment program was conducted in two phases. The first phase was baseline treatment and the second phase was the experimental treatment. The neurodevelopmental therapy (NDT), was also used in the control and study groups during the baseline treatment period (BP), three sessions per week, 60 minutes per session, for four weeks. Each session was executed by a physiotherapist, who had eight years of work experience in the neurologic rehabilitation field. The NDT requires continuous observation, evaluation, progression, and modification of the program dealing with participants' progression (23). Therefore, the physiotherapist followed the progression to choose appropriate exercises for the patient's abilities and needs. Exercises in the NDT program consisted of weight shifting in different position, facilitation of regular movement pattern (including walking), and balance activities that are based on the motorlearning principle.

During the experimental treatment period (EP), for two weeks, while the NDT was continued to use in the control group, mCIMT was conducted for the paretic lower extremity in the study group. The EP included five sessions per week, with each session lasting 120 minutes for both groups (13). The CIMT contained three main elements: the intensive practice of the functional activities, restricted use of the nonparetic extremity, and transferring the gains from the training session to the patient's real environment with "transfer package" (23). The intensive practice was applied with the selection of appropriate functional activities following the "shaping" principles by the feedback, coaching, modeling, and encouragement of the physiotherapist. The functional activities arewalking (forward, backward, sidewards), weight-bearing activities to different directions, climbing up and down stairs and ramp, balance activities, stepping over obstacles, working with a bicycle ergometer, and gait training on the treadmill, over 20 minutes, repetitively. After each 20 -minute activity period, a rest period of 5 minutes was given. A combination of two different methods fulfilled the constraint of nonparetic lower extremity; immobilization of the knee of the nonparetic extremity with a whole-leg orthosis at the fullest extension position and use of a shoe insert with a $1 \mathrm{~cm}$ lift and $5^{\circ}$ lateral wedge on the nonparetic lower extremity (Figure 1) $(9,11)$. Training on the use of the orthosis and shoe insert was provided for patients and their relatives. The restriction was used during treatment sessions and $90 \%$ of the participants' waking hours. The functional activities used during therapy session were set as a home program, and participants were strongly encouraged to use their paretic extremity (13). 


\section{Statistical Analysis}

The data were analyzed with SPSS 20.0 (IBM Corp, Chicago, IL, USA). The Kolmogorov-Smirnov test was used to determine the distribution. Variables were presented as mean \pm standard deviation. The comparisons of within-group were performed using repeated measures ANOVA, and post hoc tested via the paired sample t-test. The comparisons of the changes after treatment periods between groups were performed using Student t-test. The changes in outcome measures after the BP were evaluated with the difference between the baseline scores and post-baseline treatment scores. The changes in outcome measures during the EP were evaluated with the difference between the post-baseline treatment scores and the post-experimental treatment scores. The changes in outcome measures over the total treatment period (TTP) were evaluated with the difference between the baseline scores and post-experimental treatment scores. In addition, the changes in outcome measures were also evaluated based on minimal detectable change (MDC) values, which was determined by previous studies of Lin et al. $(24,25)$. According to these studies, the total MDC value of strength and mobility domain of SIS was 39.1, and the MDC values in the mobility, self-care, and upper extremity function subdomains of SS-QoL were 5.9, 4.0, and 5.3, respectively (25). The proportions
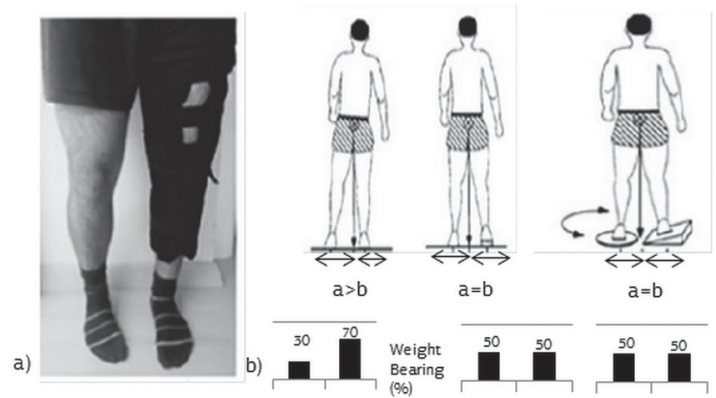

Figure 1: Constraint Method of the Nonparetic Lower Extremity: (a) Whole Leg Orthosis and (b) Addition of a Shoe Insert on the Non-Paretic Lower Extremity (9). Section "b" of this figure was used with the permission of Aruin's.

of patients with a change score greater than these MDC values were calculated. The correlation coefficient was calculated using Pearson's test to determine the developments in strength and QoL that is associated with the changes in which treatment period. The significance level was set at $\mathrm{p}<0.05$.

\section{RESULTS}

The 30 participants were 16 females and 14 males, with a mean age of $56.40 \pm 13.45$ years and the mean time post-stroke of $6.70 \pm 2.94$ months. Figure 2 demonstrates the flowchart of the study. The clinical characteristics of the participants are summarized in Table 1. Both groups were similar regarding physical characteristics at baseline

Table 1: Participant Characteristics.

\begin{tabular}{|c|c|c|c|}
\hline Characteristics & $\begin{array}{c}\text { mCIMT Group } \\
(n=15) \\
\text { Mean } \pm \text { SD }\end{array}$ & $\begin{array}{c}\text { Control Group } \\
(n=15) \\
\text { Mean } \pm \text { SD }\end{array}$ & $\mathbf{p}$ \\
\hline Age (years) & $55.13 \pm 14.70$ & $57.67 \pm 12.20$ & $0.612^{a}$ \\
\hline Poststroke (months) & $6.80 \pm 2.70$ & $6.63 \pm 3.18$ & $0.878^{a}$ \\
\hline BMI $\left(\mathrm{kg} / \mathrm{m}^{2}\right)$ & $26.26 \pm 3.49$ & $29.71 \pm 7.56$ & $0.124^{a}$ \\
\hline $\begin{array}{l}\text { Gender, n (\%) } \\
\text { Male } \\
\text { Female }\end{array}$ & $\begin{array}{l}8(53.3) \\
7(46.7)\end{array}$ & $\begin{array}{l}6(40) \\
9(60)\end{array}$ & $0.464^{b}$ \\
\hline $\begin{array}{l}\text { Affected Side, n (\%) } \\
\text { Left } \\
\text { Right }\end{array}$ & $\begin{array}{c}10(66.7) \\
5(33.3)\end{array}$ & $\begin{array}{c}10(66.7) \\
5(33.3)\end{array}$ & $1.000^{\mathrm{b}}$ \\
\hline $\begin{array}{l}\text { Type of Stroke, n (\%) } \\
\text { Ischemia } \\
\text { Hemorrhage }\end{array}$ & $\begin{array}{c}11(73.3) \\
4(26.7)\end{array}$ & $\begin{array}{l}12(80) \\
3(20)\end{array}$ & $0.666^{b}$ \\
\hline $\begin{array}{l}\text { Brunnstrom Recovery } \\
\text { III } \\
\text { IV }\end{array}$ & $\begin{array}{l}12(80) \\
3(20)\end{array}$ & $\begin{array}{c}11(73.3) \\
4(26.7)\end{array}$ & $0.666^{b}$ \\
\hline
\end{tabular}

${ }^{a}$ Student's t-Test, ${ }^{\circ}$ Chi Square Test. BMI: Body Mass Index. 


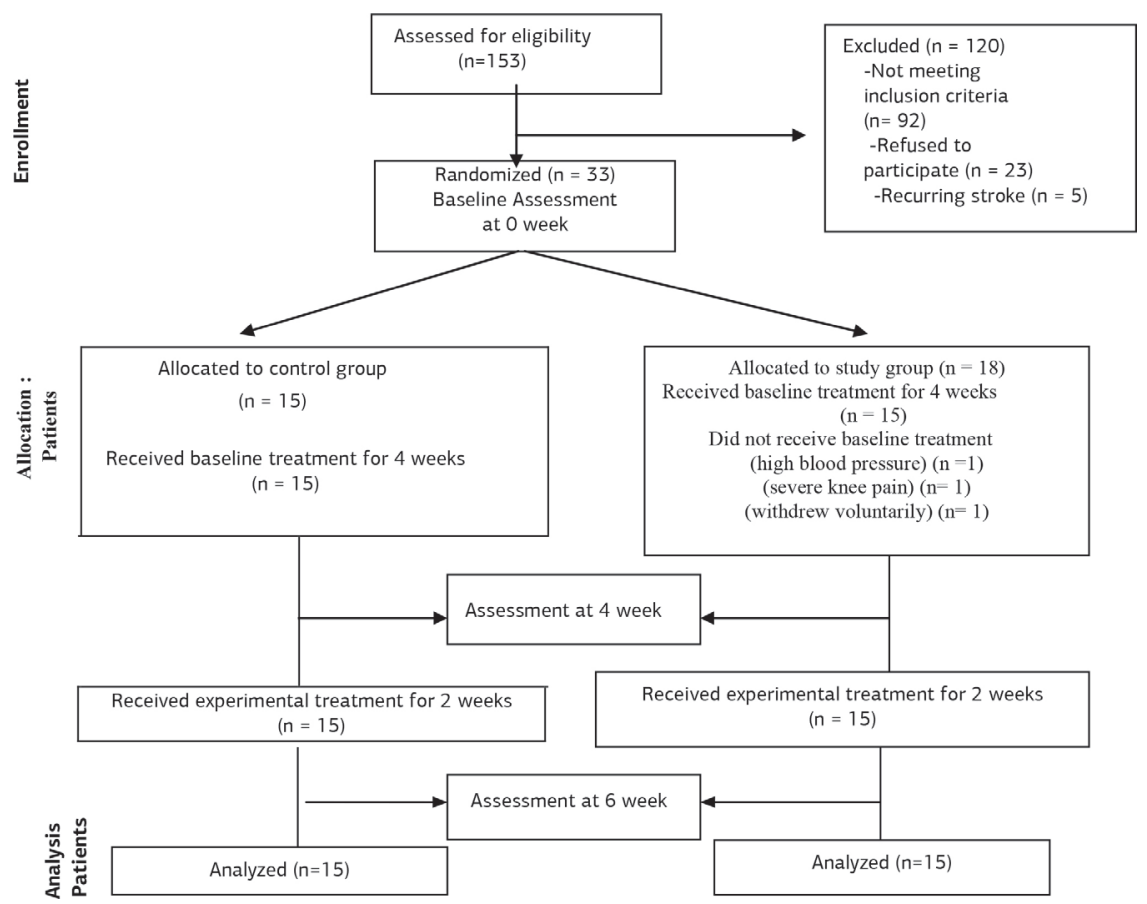

Figure 2: Study Design and Sample Flowchart.

$(p>0.05)$.

The Motricity Index score increased for BP, EP, and TTP in both groups $(p<0.01$, Table 2$)$. The score increased 19.8 and 13.2 points in the study and control group, after the TTP, respectively. A significant difference of changes in lower extremity strength was seen for the TTP in favor of the $m$ CIMT group ( $p=0.029)$, but the changes in BP and EP were found similar among groups $(p=0.161$ and $p=0.129$, Table 3).

The outcomes of the QoL improved in both groups for all treatment periods ( $p<0.01$, Table 2 ). Comparison of the changes in the SS-QoL total score and subdomain scores among groups are also detailed in Table 3. Regarding the SS-QoL total score and their subdomains, the study group showed significant improvement after the EP, in total score $(p=0.003)$, mobility $(p=0.004)$, self care $(p=0.002)$, thinking $(p=0.026)$, mood $(p=0.012)$, family $(p=0.01)$, and social roles $(p=0.004)$ when compared with the control group. The thinking $(p=0.043)$, mood $(p=0.002)$, and personality $(p=0.040)$ scores in the mCIMT group also changed meaningfully over the TTP. After the BP only the mood subdomain improved significantly in the mCIMT group $(p=0.009)$. The subdomains of energy, vision, language, work/productivity scores, and upper extremity function were similar among groups ( $p>0.05)$.

Figure 3 demonstrates that the proportions of patients exceeded the MDC values. At the BP a similar proportion of patients exceeded the
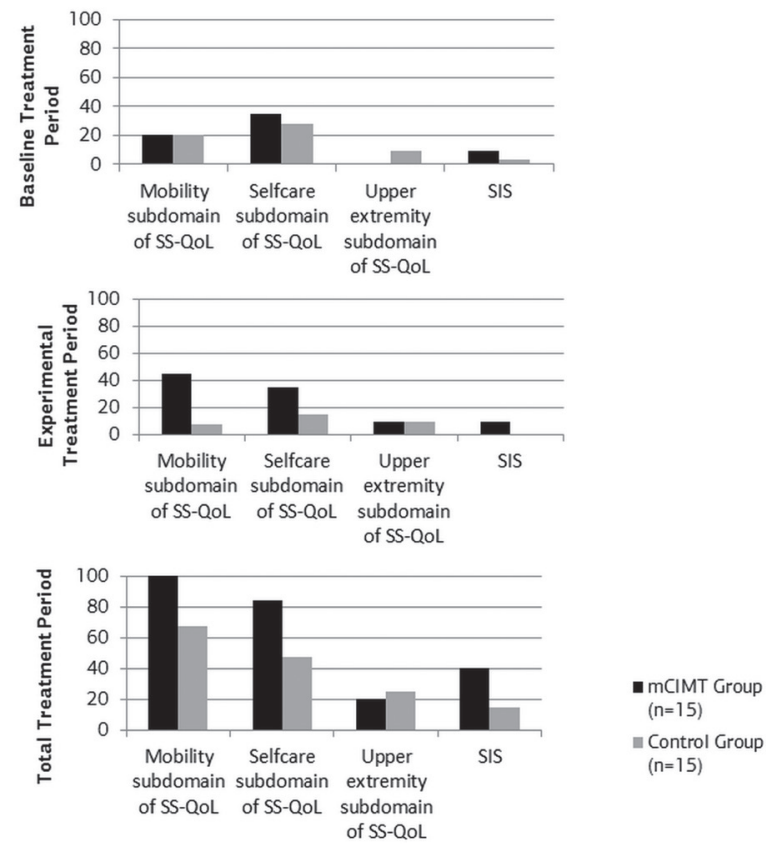

Figure 3: Comparison of the Proportions of the Patient Reached or Exceeded the Minimal Detectable Change Values between the Groups. SIS: Stroke Impact Scale, SS-QoL: Stroke Specific Quality of Life. 
Table 2: The Comparison of the Means of the Motricity Index, Stroke Specific Quality of Life Scale, and Stroke Impact Scale Scores within the Group.

\begin{tabular}{|c|c|c|c|c|c|c|}
\hline \multirow{2}{*}{$\begin{array}{l}\text { Outcome } \\
\text { Measures }\end{array}$} & \multicolumn{3}{|c|}{ mCIMT Group } & \multicolumn{3}{|c|}{ Control Group } \\
\hline & Baseline & Post-4 weeks & Post- 6 weeks & Baseline & Post-4 weeks & Post- 6 weeks \\
\hline Motricity Index & $42.13 \pm 10.27$ & $50.47 \pm 11.13^{a}$ & $61.93 \pm 12.53^{\mathrm{b}, \mathrm{c}}$ & $44.87 \pm 12.89$ & $50.13 \pm 14.86^{a}$ & $58.07 \pm 14.35^{b, c}$ \\
\hline SSQoLS Total & $128.40 \pm 29.36$ & $148.60 \pm 27.95^{\mathrm{a}}$ & $177.40 \pm 23.85^{b, c}$ & $128.87 \pm 26.95$ & $152.13 \pm 26.25^{a}$ & $166.53 \pm 25.47^{\mathrm{b}, \mathrm{c}}$ \\
\hline Mobility & $14.80 \pm 4.65$ & $18.87 \pm 4.03^{a}$ & $24.87 \pm 3.74^{b, c}$ & $12.87 \pm 3.62$ & $19.40 \pm 3.70^{a}$ & $22.60 \pm 3.09^{b, c}$ \\
\hline Energy & $8.33 \pm 2.92$ & $9.73 \pm 2.69^{a}$ & $11.07 \pm 2.58^{\mathrm{b}, \mathrm{c}}$ & $7.60 \pm 2.69$ & $8.87 \pm 3.16^{a}$ & $9.60 \pm 3.27^{b, c}$ \\
\hline Self Care & $11.53 \pm 3.52$ & $14.40 \pm 3.48^{a}$ & $17.60 \pm 3.58^{b, c}$ & $11.67 \pm 3.66$ & $14.47 \pm 3.29^{a}$ & $15.80 \pm 3.65^{b, c}$ \\
\hline Vision & $13.40 \pm 2.16$ & $14.13 \pm 1.60^{a}$ & $14.93 \pm 0.26^{b, c}$ & $13.33 \pm 1.76$ & $14.20 \pm 1.01^{\mathrm{a}}$ & $14.53 \pm 0.64^{b, c}$ \\
\hline Language & $19.27 \pm 7.33$ & $19.73 \pm 7.01^{\mathrm{a}}$ & $21.27 \pm 6.27^{b, c}$ & $20.87 \pm 6.01$ & $22.07 \pm 5.39^{a}$ & $22.67 \pm 5.04^{\mathrm{b}, \mathrm{c}}$ \\
\hline $\begin{array}{l}\text { Work/ } \\
\text { Productivity }\end{array}$ & $6.60 \pm 2.72$ & $8.20 \pm 2.76^{a}$ & $9.80 \pm 2.81^{\mathrm{b}, \mathrm{c}}$ & $6.07 \pm 1.83$ & $7.67 \pm 2.19^{a}$ & $8.53 \pm 2.36^{b, c}$ \\
\hline $\begin{array}{l}\text { Upper } \\
\text { Extremity } \\
\text { Function }\end{array}$ & $11.60 \pm 4.82$ & $13.27 \pm 5.13^{a}$ & $15.93 \pm 5.51^{b, c}$ & $11.00 \pm 3.98$ & $13.67 \pm 3.81^{\mathrm{a}}$ & $15.60 \pm 4.27^{b, c}$ \\
\hline Thinking & $9.73 \pm 2.12$ & $11.13 \pm 1.60^{\mathrm{a}}$ & $12.73 \pm 1.62^{b, c}$ & $9.67 \pm 2.41$ & $10.73 \pm 2.12^{a}$ & $11.27 \pm 1.75^{\mathrm{b}, \mathrm{c}}$ \\
\hline Personality & $7.13 \pm 3.16$ & $8.67 \pm 2.53^{a}$ & $10.40 \pm 2.77^{b, c}$ & $8.60 \pm 4.03$ & $9.60 \pm 3.70^{a}$ & $10.60 \pm 3.04^{b, c}$ \\
\hline Mood & $10.47 \pm 3.80$ & $13.93 \pm 3.79^{a}$ & $17.07 \pm 3.49^{b, c}$ & $11.60 \pm 3.04$ & $13.80 \pm 2.83^{a}$ & $15.87 \pm 2.83^{b, c}$ \\
\hline Family & $6.20 \pm 3.14$ & $7.87 \pm 3.11^{\mathrm{a}}$ & $10.00 \pm 3.25^{b, c}$ & $6.67 \pm 2.16$ & $8.33 \pm 2.61^{\mathrm{a}}$ & $9.33 \pm 2.74^{\mathrm{b}, \mathrm{c}}$ \\
\hline Social Rolles & $8.87 \pm 3.46$ & $11.40 \pm 4.37^{\mathrm{a}}$ & $14.13 \pm 5.21^{\mathrm{b}, \mathrm{c}}$ & $8.67 \pm 2.13$ & $11.47 \pm 3.16^{a}$ & $12.80 \pm 3.55^{b, c}$ \\
\hline SIS $^{d}$ & $31.21 \pm 19.12$ & $53.05 \pm 19.45^{a}$ & $70.91 \pm 15.54^{b, c}$ & $37.88 \pm 21.17$ & $53.64 \pm 17.71^{a}$ & $64.83 \pm 17.13^{b, c}$ \\
\hline $\begin{array}{l}\text { Perceived } \\
\text { Recovery }\end{array}$ & $21.33 \pm 14.07$ & $42.67 \pm 12.23^{a}$ & $72.67 \pm 15.80^{\mathrm{b}, \mathrm{c}}$ & $24.67 \pm 11.87$ & $41.33 \pm 12.46^{a}$ & $57.33 \pm 15.34^{\mathrm{b}, \mathrm{c}}$ \\
\hline
\end{tabular}

a Means that the scores changed significantly between the baseline and post 4 weeks assessment. $p<0.01$.

bMeans that the scores changed significantly between the post 4 weeks and post 6 weeks assessment. $p<0.01$.

cMeans that the scores changed significantly between the baseline and post 6 weeks assessment. $p<0.01$.

dSIS: Stroke Impact Scale, the domain of strength of lower extremity and mobility.

SSQoLS: Stroke Specific Quality of Life Scale. mCIMT: Constraint Induced Movement Therapy.

MDC value in both groups for mobility and upper extremity function subdomains. At the EP and TTP, these proportions increased for mobility and selfcare subdomains in both groups, but in the mCIMT group 2 -fold more patients obtained these values. The proportion of patients exceeded the MDC values of upper extremity function was the lowest level for both groups.

As shown in Table 2, SIS score changed more over TTP in the study group compared with the control group $(p=0.017)$, but the improvement in the $B P$ and EP did not differ between groups $(\mathrm{p}=0.118$ and $\mathrm{p}=0.051)$. In the $\mathrm{mCIMT}$ group, the SIS subdomain of the amount of perceived recovery improved significantly more than the control group after the TTP $(p<0.001)$ and EP $(p<0.001)$.

The change at the end of the TTP for the SIS score exceeded the MDC value in the $40 \%$ proportions of the mCIMT group and $13.3 \%$ of the control group. The changes of SIS score in the BP and EP exceeded the MDC value less than $10 \%$ of patients for both groups (Figure 3).

For the improvements in strength and QoL of both groups, the correlations between total change and change in BP and between total change and change in EP are shown in Figure 4. Correlations were found to be significantly strong on the following items: strength (correlation coefficient of BP vs. $E P, r=0.660$ vs $r=0.709$, respectively), and QoL of EP $(r=0.769)$. The correlation between total score change and BP in QoL was moderate $(r=0.505$, $p<0.010$ ).

\section{DISCUSSION}

This study revealed that $\mathrm{mCIMT}$ for the paretic lower extremity improves muscle strength and health- 


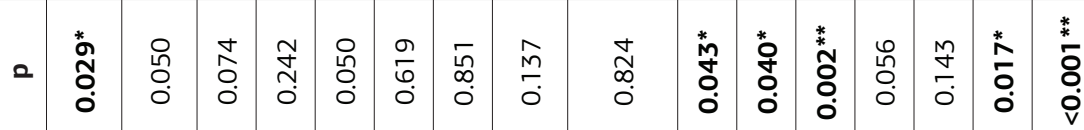

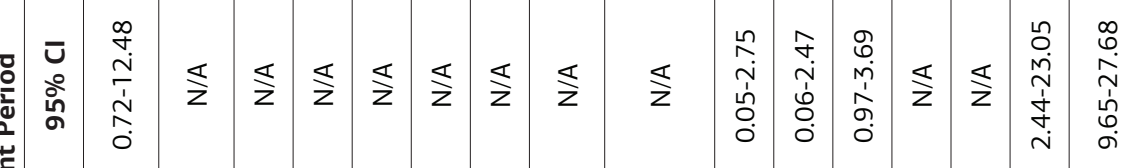

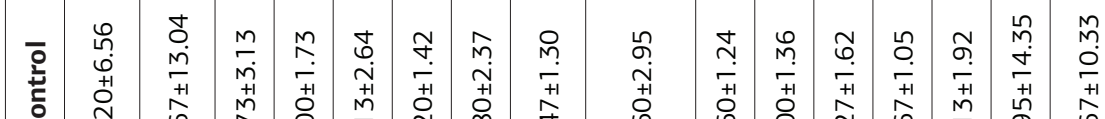

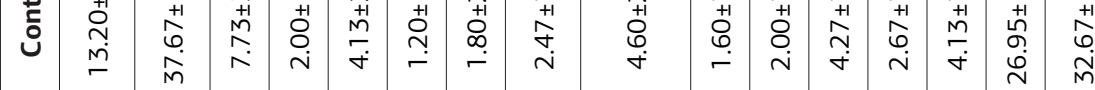
ヘ

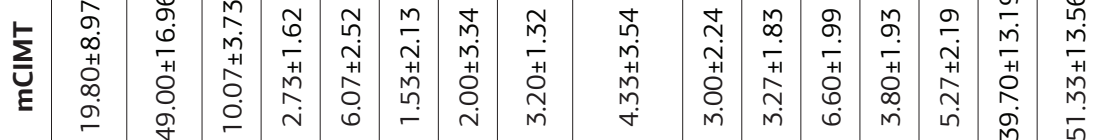

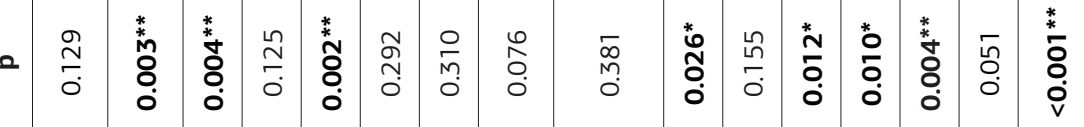

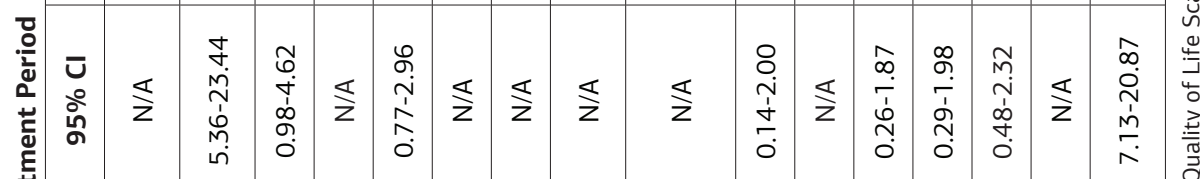

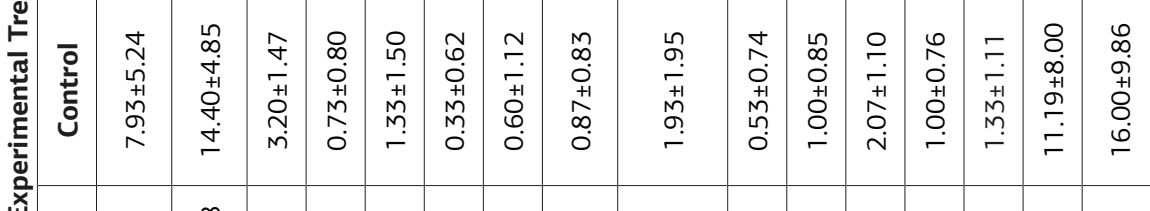

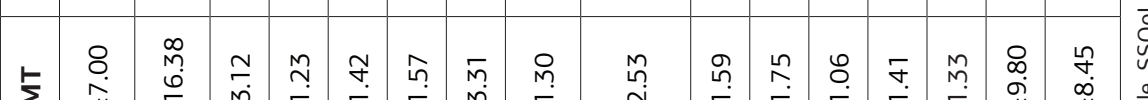

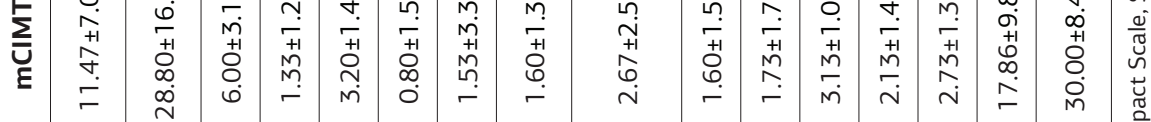

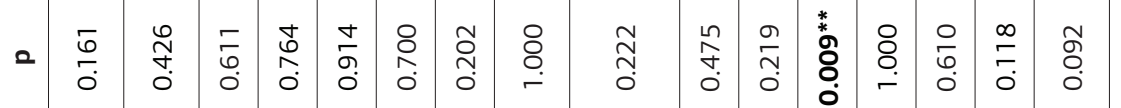

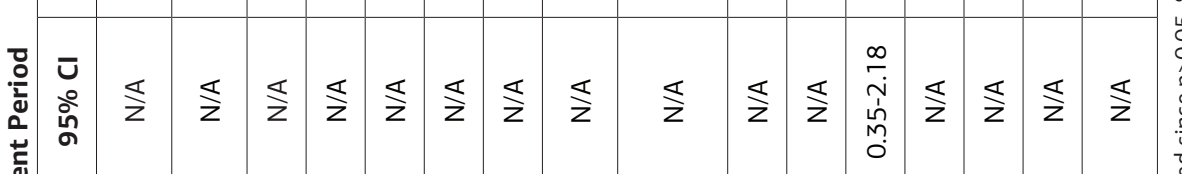

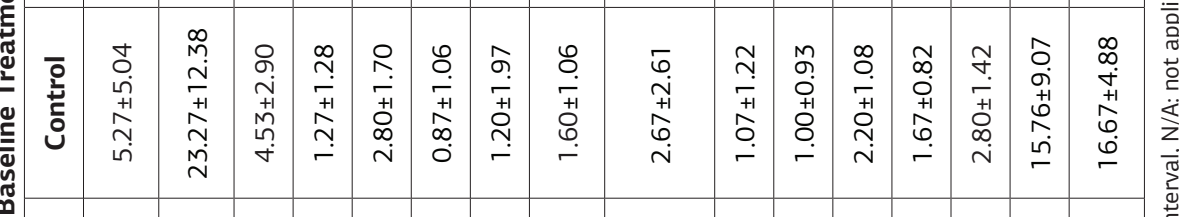

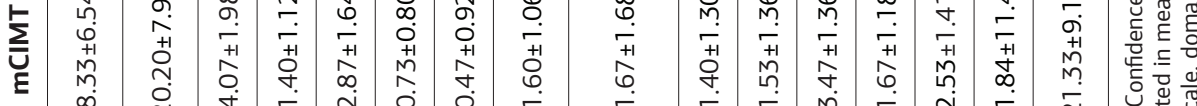




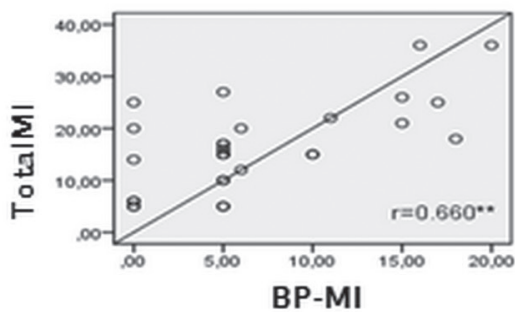

1.a

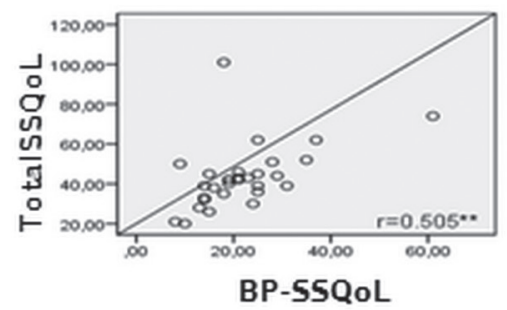

2. a

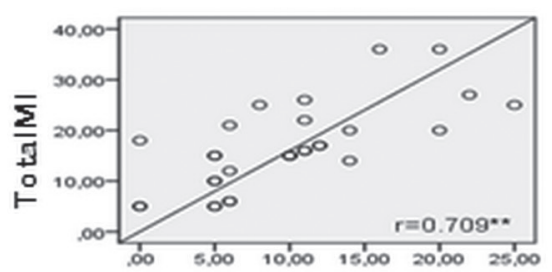

EP-MI

1.b

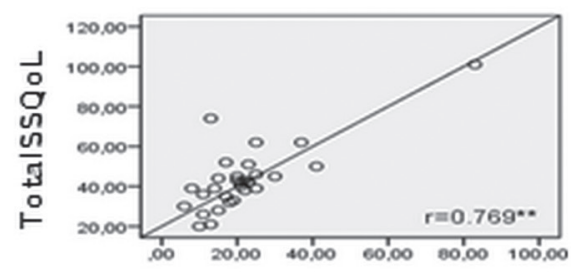

EP-SSQoL

2.b

Figure 4: This figure illustrates correlations (1.a) among total strength change and strength change of baseline treatment, (1.b) among total strength change and strength change of experimental treatment, (2.a) among total change of QoL score and change of QoL score in baseline treatment, and (2.b) among total change of QoL score and change of QoL score in experimental treatment. BP: change in baseline treatment period, EP: change in experimental treatment period, MI: Motricity Index, SSQoL: Stroke Specific Quality of Life. ${ }^{* *} p<0.01$, r: Pearson's correlation coefficient.

related QoL in patients with stroke, particularly the mobility, self-care, thinking, mood, family, and social roles subdomains. mCIMT can be used as a supportive treatment method to improve the QoL and increase the muscle strength, as a result of the development of paretic lower extremity function, following the stroke.

After the stroke, many approaches consisting of exercise are recommended to improve motor function and health-related QoL (5). Modified CIMT is another method that has been used recently to improve functional performance, particularly concerning gait and balance outcomes (10,1214,26). We also published a paper, as a primary result of this study, which demonstrated that mCIMT enhanced the motor function (10). However, outcomes of QoL and strength, as well as motor function, are essential in evaluating the success of an approach.

The assessment and development of muscle strength are essential following a stroke, as muscle weakness probable cause to chronic disability. In this study, in which we examined the effect of mCIMT on muscle strength, we showed that strength improvement in the study group was higher than the control group after the TTP.
Moreover, the improvement after the TTP was correlated more highly with the EP, in particularly $\mathrm{mCIMT}$. Our finding is consistent with the previous studies in which reported that task-oriented rehabilitation methods, such as mCIMT, are beneficial for increasing muscle strength $(15,27)$. We thought that the strength development after TTP in the study group is explained by the right, intensive practice of the paretic lower extremity in weight-bearing positions due to the restriction of non-paretic extremity. Therefore, the muscles in the paretic lower extremity may have been extensively activated, and inconsequently the strengthening has occurred.

Gokkaya et al. (28) reported that QoL is poorer in Turkish stroke survivor than in healthy individuals. One of the significant aims of rehabilitation is to improve QoL. The QoL is closely related to ensuring independence in activities of daily living, especially in the successful continuation of mobility. Therefore, the rehabilitation approaches should target to achieve the lower-extremity functions to an optimal level, which are known in the linear relationship with QoL $(4,28,29)$. Yu et al. have reported that there were superior effects of forceduse training for the affected lower extremity on gait, 
but it did not result in better QoL (30). In contrast, we showed that mCIMT had positive effects on QoL, particularly total score, mobility, self-care, social roles, family, mood, thinking subdomains of SS-QoL. In addition, sometimes these changes may not be enough to make a clinical decision. At this point, the MDC values may help the clinician to interpret the outcomes. Thus, the physiotherapist could decide whether to proceed or needs to change the treatment. MDC values of the SS-QoL scale was reported just mobility, self-care and upper extremity function subdomains (25). The present study showed that the highest proportions of the patients in study groups had an actual improvement in mobility and self-care subdomains of SS-QoL. We attributed this finding that mCIMT for lower extremity involved the intensive practice of the paretic extremity and increased weight-bearing on the paretic lower extremity (10), and following the mobility, transfer activities and participation improved due to treatment. Consequently, these changes have reflected the QoL.

The patient's thoughts dealing with the treatment methods should be considered, which will help to ensure that the treatment is successful. The SIS includes a domain that evaluates perceived recovery by the patient. Participants have reported that $\mathrm{mCIMT}$ contributes more to recovery from the stroke after both the EP and TTP when compared with NDT. When QoL is evaluated using the SIS, QoL has been seen to develop further in the MCIMT group by the effect of total treatment. In this study, only the mobility and lower extremity strength domains of the SIS were used. Therefore, the impact of stroke recovered after six weeks due to the development of strength.

Similarly, at the BP and EP, only one patient exceeded the MDC value of the SIS in both groups, and after the TTP, $40 \%$ and $13.3 \%$ of the patients in the mCIMT group and the control group, respectively, exceeded the MDC value. This finding suggested that enhancement of SIS after TTP was relating to the strength development. The increased QoL is desired due to the strengthening effect of mCIMT. The mCIMT for 2-weeks can be used interchangeably with other treatment modalities which support motor learning such as NDT. This combined approach may facilitate neural plasticity and accelerate recovery. For instance, mCIMT for lower extremity can be performed for 2-weeks following NDT with four weeks to improve QoL in stroke.

This study was a preliminary study which was used to a double restriction method by knee immobilizer and shoe insert, and we did not predict the patient adherence to the restricting method. Since our patients did not attend any rehabilitation programme, four weeks of baseline treatment was conducted to prepare for intensive EP. Consequently, we applied mCIMT for two weeks that is more effective than four and six weeks of treatment for task-oriented training as it has been shown in a previous study (27). The patient adherence to treatment, and orthosis was observed well. Therefore double restriction method can be confidently used to improve muscle strength and QoL.

Patients in both groups were encouraged to pursue their daily life and home program. However, adherence to the home program and the wear time of the restriction orthosis out of the session was not monitored. We thought that this was one limitation of the present study. Although both groups received the same intensity treatment, the mCIMT group arguably received more "treatment" due to restriction orthosis and transfer package. This point is regarded as a common limitation of all CIMT studies. Another limitation was the lack of proportions of patients who exceeded the MDC value of Motricity Index, SS-QoL total score, and its other subdomains. There was no study relating to these MDC values in the literature. The other limitations of our study include the findings could only be generalized to patients who met the inclusion criteria and the lack of evaluations of the participants' activity levels before treatment. The physical activity level may be a predictive factor. The effect of mCIMT according to the activity levels of the patients can be investigated with further studies. Besides these limitations, this study also had several strengths. The main strengths of this study were being a randomized controlled study, being the first study to show the effects of mCIMT, as applied to the lower extremities on QoL and strength, and last QoL had been considered comprehensively. 
In conclusion, mCIMT for paretic lower extremity resulted in improvements in QoL after the EP and TTP, and in strength after the TTP. Furthermore, the improvements in TTP were correlated strongly with the EP.

Sources of Support: There has been no financial support for this research.

Conflict of Interest: The authors have no conflict of interest to declare.

Ethical Approval: Hacettepe University Ethics Committee approved this study protocol (Approval no: GO 14/22-15).

Informed Consent: Written informed consent was obtained from all study participants.

Acknowledgements: The authors would like to show their gratitude to the participating hospitals, all the patients, their families, and physiotherapists who attended to this work. This study was presented at the 1st International Health Science and Life Congress on May 2-5, 2018 as a poster presentation.

\section{REFERENCES}

1. Ferrarello F, Baccini M, Rinaldi LA, Cavallini MC, Mossello E, Masotti G, et al. Efficacy of physiotherapy interventions late after stroke: a meta-analysis. J Neurol Neurosurg Psychiatry. 2011;82(2):136-43.

2. Group W. The World Health Organization Quality of Life assessment (WHOQOL): position paper from the World Health Organization. Soc Sci Med. 1995;41(10):1403-9.

3. Muus I, Petzold M, Ringsberg KC. Health-related quality of life among Danish patients 3 and 12 months after TIA or mild stroke. Scand J Caring Sci. 2010;24(2):211-8.

4. Carod-Artal FJ, Trizotto DS, Coral LF, Moreira CM. Determinants of quality of life in Brazilian stroke survivors. J Neurol Sci. 2009;284(1-2):63-8.

5. Pollock A, Baer G, Campbell P, Choo PL, Forster A, Morris J, et al. Physical rehabilitation approaches for the recovery of function and mobility following stroke. Cochrane Database Syst Rev. 2014;4:Cd001920.

6. Taub E, Uswatte G, Mark VW, Morris DM. The learned nonuse phenomenon: implications for rehabilitation. Eura Medicophys. 2006;42(3):241-56.

7. Billinger SA, Guo LX, Pohl PS, Kluding PM. Single limb exercise: pilot study of physiological and functional responses to forced use of the hemiparetic lower extremity. Top Stroke Rehabil. 2010;17(2):128-39.

8. Sibley KM, Tang A, Brooks D, Brown DA, Mcllroy WE. Feasibility of adapted aerobic cycle ergometry tasks to encourage paretic limb use after stroke: a case series. J Neurol Phys Ther. 2008;32(2):80-7.

9. Aruin AS, Rao N, Sharma A, Chaudhuri G. Compelled body weight shift approach in rehabilitation of individuals with chronic stroke. Top Stroke Rehabil. 2012;19(6):556-63.

10. Acaroz Candan S, Livanelioğlu A. Effects of modified constraint induced movement therapy for lower limb on motor function in stroke patients: a randomized controlled study. Int J Physiother. 2017;4(5):269-77.
11. Marklund I, Klassbo M. Effects of lower limb intensive mass practice in poststroke patients: single-subject experimental design with long-term follow-up. Clin Rehabil. 2006;20(7):56876.

12. Kallio K, Nilsson-Wikmar L, Thorsen AM. Modified constraintinduced therapy for the lower extremity in elderly persons with chronic stroke: single-subject experimental design study. Top Stroke Rehabil. 2014;21(2):111-9.

13. Zhu Y, Zhou C, Liu Y, Liu J, Jin J, Zhang S, et al. Effects of modified constraint-induced movement therapy on the lower extremities in patients with stroke: a pilot study. Disabil Rehabil. 2016;38(19):1893-9.

14. Mishra S, Chitra J. Effect of modified constraint induced movement therapy (mCIMT) for lower limb on weight bearing symmetry and balance in stroke patients: a pre-post experimental study. Int J Sci Res. 2014;3(6):485-8.

15. Wu CY, Chen CL, Tsai WC, Lin KC, Chou SH. A randomized controlled trial of modified constraint-induced movement therapy for elderly stroke survivors: changes in motor impairment, daily functioning, and quality of life. Arch Phys Med Rehabil. 2007;88(3):273-8.

16. Bayona NA, Bitensky J, Foley N, Teasell R. Intrinsic factors influencing post stroke brain reorganization. Top Stroke Rehabil. 2005;12(3):27-36.

17. Cameron D, Bohannon RW. Criterion validity of lower extremity Motricity Index scores. Clin Rehabil. 2000;14(2):208-11.

18. Fayazi M, Dehkordi SN, Dadgoo M, Salehi M. Test-retest reliability of Motricity Index strength assessments for lower extremity in post stroke hemiparesis. Med J Islam Repub Iran. 2012;26(1):27-30.

19. Hakverdioglu Yont G, Khorshid L. Turkish version of the StrokeSpecific Quality of Life Scale. Int Nurs Rev. 2012;59(2):274-80.

20. Williams LS, Weinberger M, Harris LE, Clark DO, Biller J. Development of a stroke-specific quality of life scale. Stroke. 1999;30(7):1362-9.

21. Ozmaden Hantal A, Dogu B, Buyukavci R, Kuran B. Stroke Impact Scale Version 3.0: study of reliability and validity in stroke patients in the Turkish Population. Turk J Phys Med Reh. 2014;60:106-16.

22. Muren MA, Hutler M, Hooper J. Functional capacity and healthrelated quality of life in individuals post stroke. Top Stroke Rehabil. 2008;15(1):51-8

23. Morris DM, Taub E. Constraint-induced therapy approach to restoring function after neurological injury. Top Stroke Rehabil. 2001;8(3):16-30.

24. Lin KC, Fu T, Wu CY, Wang YH, Liu JS, Hsieh CJ, et al. Minimal detectable change and clinically important difference of the Stroke Impact Scale in stroke patients. Neurorehabil Neural Repair. 2010;24(5):486-92

25. Lin KC, Fu T, Wu CY, Hsieh CJ. Assessing the stroke-specific quality of life for outcome measurement in stroke rehabilitation: minimal detectable change and clinically important difference. Health Qual Life Outcomes. 2011;9:5.

26. Numata K, Murayama T, Takasugi J, Oga M. Effect of modified constraint-induced movement therapy on lower extremity hemiplegia due to a higher-motor area lesion. Brain Inj. 2008;22(11):898-904.

27. Jeon BJ, Kim WH, Park EY. Effect of task-oriented training for people with stroke: a meta-analysis focused on repetitive or circuit training. Top Stroke Rehabil. 2015;22(1):34-43.

28. Gokkaya NK, Aras MD, Cakci A. Health-related quality of life of Turkish stroke survivors. Int Journal Rehabil Res. 2005;28(3):22935.

29. Nor Azlin MN, Aziz NA, Saperi BS, Aljunid SM. Functional limitation and health-related quality of life, and associated factors among long term stroke survivors in a Malaysian community. Med J Malaysia. 2016;71(6):313-21.

30. Yu WH, Liu WY, Wong AM, Wang TC, Li YC, Lien HY. Effect of forced use of the lower extremity on gait performance and mobility of post-acute stroke patients. J Phys Ther Sci. 2015;27(2):421-5. 